\title{
ROSS'S CONCEPT OF THE LEGAL CONSCIOUSNESS AND DELIBERATE NORMATIVE CHANGE
}

Summary: $\quad$ Deliberate normative change is a vital process in modern legal orders, although it is often perceived as a peripheral aspect in the theory of law. The article analyses the views of Alf Ross on the role of the legal consciousness in explaining deliberate normative change, and develops further some of his insights with an aim of presenting its applicability to researching contemporary legal processes. Although neglected in legal theory, Ross's conception of deliberate normative change is a significant contribution to understanding and study of legal practice and represents an integral part of his general theory of law, especially in view of his scientific approach to law.

Keywords: $\quad$ legal consciousness, deliberate normative change, Alf Ross, science, normative influence

\section{INTRODUCTION: THE IMPORTANCE OF ROSS'S THEORY AND METHODOLOGY}

According to Jeremy Waldron, legal theory often perceives deliberate law-making as 'a contingent and philosophically peripheral aspect of law', and modern positivists are much less interested in deliberate legislation than in courts. ${ }^{1}$ Alf Ross has dedicated the larger part of his book On Law and Justice ${ }^{2}$ to this matter whereby, contrary to Waldron, he considers this part of his theory as a component of both adjudication and legislation. Surprisingly, his conception of deliberate normative change has not attracted much attention among legal scholars. We

Mario Krešić, PhD, Assistant Professor, Faculty of Law, University in Zagreb, Republika Hrvatska Square 14, 10000 Zagreb, Republic of Croatia. Email address: mario.kresic@pravo.hr. ORCID: https://orcid.org/0000-0002-0014-4157.

1 Jeremy Waldron, The Dignity of Legislation, Cambridge University Press, New York, 1999, at 15 and 16.

2 Alf Ross, On Law and Justice, The Lawbook Exchange, Ltd, Clark, New Jersey, 2004. 
propose two arguments as to why Ross's theory on intentional normative change should be acknowledged as an essential segment of his work. Firstly, it presents consistent conceptual ground which can be further developed to serve as a theoretical tool for understanding and researching the contemporary practices of legal practitioners involved in changing the legal system. Secondly, it is an integral part of his general theory of law and cannot be disregarded without overlooking the whole picture of law that Ross has developed in his work.

Justification of the first argument is the primary aim of this article. We will present and re-construct Ross's theory to emphasize the measurable elements which can be relevant for a theoretical and practical comprehension of contemporary legal processes. Where suitable, Ross's hypothesis will be further developed, and an elaboration of normative influence on the formal legal consciousness will be added as a contribution to his theory. The second argument requires a detailed description of Ross's key concepts and methodology which is not the primary purpose of this article. ${ }^{3}$ Nevertheless, for the purpose of explaining his methodological approach to deliberate normative change, we will outline the main thesis on his methodology which can be used in favour of this second argument. In the context of his methodology the concept of the legal consciousness appears as an important element for his general theory of law. We propose that Ross's theory on deliberate normative change be understood as the result of his scientific approach to law whereby the concept of the legal consciousness has an essential methodological and explanatory role. Namely, his general theory of law is based on several methodological positions. Two of them - the monistic ontology of law ${ }^{4}$ and the scientific approach to law - can be seen as realistic propositions on law in opposition to some legal positivist theories. Ross's scientific approach to law can be interpreted as consisting of two stages: a) describing the existing activities of the participants in different practices connected to law and b) explaining these practices through the scientific model of practice. ${ }^{5}$ The claim regarding the contradiction between the empirical and the prescriptive in Ross's study ${ }^{6}$ could be refuted if the scientific model of practice is perceived as one of the possible models that may be, but does not necessarily have to be, adopted in practice.

According to Ross what distinguishes scientific from non-scientific descriptions of reality and models of its functioning is the possibility of falsifying the theories. ${ }^{7}$ Besides falsifiability, Ross's scientific approach to law includes other characteristics: the above-mentioned monistic ontology, as well as rationality and non-cognitivism. In this context, his concept of the legal consciousness performs several functions in Ross's scientific approach to law. 1) It contributes to the 'establishment' of ontological monism as the 'connecting operator' between norms

3 An instructive framework for researching Ross's methodology can be found in Edoardo Fittipaldi's main tenets of continental realism. See: Edoardo Fittipaldi, Introduction: Continental Legal Realism in: Enrico Pattaro, Corrado Roversi (ed.), Legal Philosophy in the Twentieth Century: The Civil Law World, Tome II, Springer, 2016, at 297-318.

4 Ross refutes the jurisprudence which considers the world of ideas as entities separated from physical and psychic phenomena in time and space. Ross, op. cit. (note 2), at 65.

5 According to Jakob v. H. Holtermann, "Ross's goal is epistemological, i.e. to show how the doctrinal study of law can be possible as a science. Unlike Hart, he is not interested [or not only] in ordinary usage of legal terms per se." Jakob v. H. Holtermann, A Straw Man Revisited: Resettling the Score between H.L.A. Hart and Scandinavian Legal Realism, 57 Santa Clara L. Rev. 1 (2017), at 21.

6 Rorty, Amelie O., On Law and Justice by Alf Ross Review, Ethics, Vol. 70, No. 2 (Jan., 1960), at 177.

7 Karl Popper's response to the demarcation problem between science and pseudoscience was the falsifiability of the theory. Karl Popper, The Logic of Scientific Discovery, Routledge, London and New York, 2002. 
and behaviour, and 2) enables implementation of the falsifiability thesis. ${ }^{8}$ 3) The concept also serves to strengthen his non-cognitivist and rationality thesis. Besides its methodological importance, the idea of the legal consciousness has important explicatory roles. 4) It contributes to our understanding of the roots of the specific content of a particular legal order, and 5) it helps to support predictions on the result of legal processes. Both explicatory roles are connected with the goals of the scientific approach to law: to explain reality and predict future incidents.

We suggest that Ross's scientific approach to law can be recognized not only in his views on legal scientists' practices but also in his analysis of deliberate normative change. In that light, it is not surprising to find the concept of the legal consciousness performing the same functions in Ross's explanation of deliberate normative change as in his general theory of law.

The article consists of four chapters. After the first introductory chapter on the importance of the subject and methodological remarks, in the second chapter the key elements of the theory on deliberate normative change will be exposed. The third chapter is dedicated to normative influence on the harmonization of the legal consciousness with the cultural consciousness as the most elaborated part of Ross's theory. Finally, in conclusion, we will present how his theory fits in his scientific approach to law.

\section{DELIBERATE NORMATIVE CHANGE}

\subsection{GENERAL REMARKS ON DELIBERATE NORMATIVE CHANGE IN ROSS'S THEORY}

Ross's theory on deliberate normative change can be briefly presented as the following. (1) The theory includes a description of the existing practice as well as a scientific model of how this practice could be governed. (2) It refers to the practice of both the legislator and judges. (3) Our understanding of the goals of deliberate normative change includes a description of existing practices on the selection of goals and the scientific model of selecting the goals. (4) The understanding of the methods of the realisation of the goals is part of the scientific discipline of applied legal sociology as an understanding of how legal norms affect behaviour. ${ }^{9}$ We can recognize Ross's intention to distinguish two types of this understanding of methods which are closely connected: (a) the description of the facts determining the practice of deliberate normative change, ${ }^{10}$ and (b) the scientific model on how to use norms to deliberately influence the acceptance of normative change.

Regarding the understanding of the selection of goals, Ross has rejected the scientific possibility of establishing any a priori set aims of deliberate normative change as the only

8 The legal consciousness makes the connection between normative language and the factual world (ontological monism). It is suitable for empirical testing (falsifiability of scientific theories).

9 Ross, op. cit. (note 2) at 332.

$10 \quad$ Ibid. at 336. 
true doctrine on goals. ${ }^{11}$ The doctrines on goals are contingent depending on different conceptions of the world. His hostility towards natural law doctrines make him "[...] smell the rat of Natural Law in every moral position not prostrate before the methods of sciences." ${ }^{12}$ This non-cognitivist position can lead to the conclusion that the only criterion to value the result of deliberate normative change is acceptance by others, particularly those in power. ${ }^{13}$ However, this relativist position on the goals of deliberate normative change has to be complemented with Ross's views developed in his book Why Democracy? ${ }^{14}$ In the first step, Ross reiterated his non-cognitivist position that it is impossible to ascertain scientifically what is the absolute good and consequently concluded that if a person dislikes democracy it is not possible to prove logically to him that he is making a mistake. ${ }^{15}$ The next step is that Ross considers it possible to describe and discuss the consequences of democracy and other models of government although ultimately it is not possible in any concrete case to guarantee that autocracy will not have preferable consequences for someone. ${ }^{16}$ Nevertheless, in the third step a choice has to be made between, on the one hand, the values of discussion, intellectual liberty, autonomy and the absence of arbitrariness which are the values of his democratic model, and the opposite values characteristic for autocracies on the other hand. ${ }^{17}$ We can add that the first group of values corresponds to the values of scientific cognition and leads to rational choices based on arguments. The convergence of the values of his democratic model and science can be recognized in Ross's requirements, mentioned later in this article, for open communication channels at the disposal of public debate and for the demonstration of experiences regarding controversial differences. Another scientific position regarding goals is Ross's preference for the satisfaction of human needs rather than irrational attitudes as we can see in his attempt to rationalize the legal consciousness discussed later in this article. Therefore, the choice for practitioners is the choice between scientific and other models of selecting goals.

The first sub-domain of understanding on methods is reflected in Ross's claim that the legal consciousness influences the legal system..$^{18}$ According to Ross, laws adopted against the popular legal consciousness may have undesirable effects on general law abidance. ${ }^{19}$ We can add that the legal consciousness as a fact also has a crucial effect on what judges do in all decisions, especially when culture operates as a direct source of law and when judges under their legal consciousness 'by fitting argumentation' create a norm different to those which could be detected in the statute. ${ }^{20}$ Consequently, Ross's theory on the prediction of judges' decisions is impossible without considering the influence of the legal consciousness on the decisions of judges.

\footnotetext{
11 Ibid. at 297.

12 H.L.A. Hart Essays in Jurisprudence and Philosophy, Oxford University Press, 1983 at 163. In regard to Ross's theory on legal politics, Hart has only confirmed that the author said much that is still worth saying and criticized his radical position against any "expression of morality".

13 Ibid.

14 Alf, Ross, Why Democracy? Harvard University Press, 1952.

15 Ibid. at 92.

16 Ibid. at 96 .

17 Ibid. at. 138.

18 Ross, op. cit. (note 2) at 328.

19 Ibid. at 372.

20

Ibid. at 99, 139.
} 
The second sub-domain of understanding on methods can be seen primarily in his claim that the legal system influences the legal consciousness. ${ }^{21}$ This understanding belongs to what is today known as social engineering. According to Ross, the legislator is a 'social technician who through the mechanism of law shapes social evolution. ${ }^{22} \mathrm{He}$ is aware that sometimes the popular legal consciousness does not correspond to what is needed in society according to the standards of the norm-creator. For example, Ross himself considers that there should not be criminal punishment in the case of moral disapproval of someone's way of life on condition that it does not affect the interests of others. This position can be in opposition to the popular consciousness which requires such punishments only because some pattern of behaviour represents a sinful way of life. ${ }^{23}$ In this domain of understanding, the question arises for law-makers: 'How do we influence citizens or specific groups of officials by a change of the legal system in a way that leads them to accept new norms in the system?' The influence can be structured through non-normative and normative influences.

The conception on normative influence has been indicated by Ross in several places. It shares some common points with the sociological jurisprudence of Roscoe Pound and Eugen Ehrlich, ${ }^{24}$ as well as with the Scandinavian realist approach to legislation of Axel Hägerström and Karl Olivecrona. ${ }^{25}$ Nevertheless, when all elements are put together it represents a unique theory which cannot be reduced to any other theories. The segments of Ross's normative influence theory put together in a systematic way can be described as the following:

1. Action consists of interested or disinterested attitudes and operational beliefs;

2. Attitudes are conditioned by each other through established operational beliefs;

3. Certain normative techniques can influence attitudes and operational beliefs, and the basics on these techniques can be recognized in Ross's writing on the efficiency of law and disagreements on attitudes;

4. There are factors which can limit the possibility of influence.

5. The legal consciousness - a set of disinterested attitudes - is the central element for structuring normative influence;

6. The legal consciousness itself is determined by the cultural consciousness which influences attitudes towards all legal and non-legal norms in society;

7. The cultural consciousness is determined by technology understood in the broader sense and the prevailing conceptions of reality. It can be changed by modification of these two factors, and we can add to Ross's view on the cultural consciousness that normative influence can also be aimed at the modification of the cultural consciousness through its influence on these two factors;

21 Ibid. at. 328.

22 Ibid. at 355.

23 Ibid. at 373.

24 For example, Pound's concept on "the law in action" and Ehrlich's concept of "the living law". For the difference between these two concepts see: Marc Hertogh, A `European’ Conception of Legal Consciousness: Rediscovering Eugen Ehrlich, Journal of Law and Society, Volume 31, Number 4.

25 For example, Hägerström's non-cognitivism reflected in law-making and Olivecrona's thesis on the effect of legislation conditioned by the psychological attitude. For some insights on the legislation of these two authors see: Patricia Mindus, Axel Hägerström, On Law-making, and Torben Spaak, Karl Olivecrona on Legislation in: The Theory and Practice of Legislation, Realist Conceptions of Legislation, eds. P. Brunet, E. Millard, P. Mindus, Volume 1, Number 1, June 2013. 
8. The legal consciousness may be modified through influencing disinterested attitudes, and under certain circumstances through influencing interested attitudes;

9. Based on Ross's differentiation of two types of legal consciousness, we can differentiate two types of normative influence on the legal consciousness: the first is aimed at the material legal consciousness for the acceptance of norms on behaviour, and the second is aimed at the formal legal consciousness for the acceptance of norms on changing and applying the law;

10. There are two main types of modification of the legal consciousness which can be based on two of Ross's thesis: the law is created to adapt the legal consciousness to the cultural consciousness and culture evolves itself.

The first four elements of the theory are applicable to normative influence on both evolutions of norms: through practical considerations on norms and through the legal consciousness. In the following chapter we will focus on normative influence on the legal consciousness (elements 6-10) as the central element of Ross's theory, and before we start, we will briefly explain the concept of the legal consciousness itself (element 5).

\subsection{ROSS'S CONCEPT OF THE LEGAL CONSCIOUSNESS}

The concept of the legal consciousness is the central element of Ross's theory on deliberate normative change. He describes the legal consciousness as consisting of "disinterested attitudes of approval or disapproval of the social norm." In differentiating between this and other attitudes towards social norms, for example moral norms which refer to personal relations, the attitudes of the legal consciousness are seen as referring to the organized regulation of community life ${ }^{26}$ that is to the legal order and particular legal norms. An important characteristic of the attitudes of the legal consciousness is the same as for moral attitudes: they are both disinterested attitudes. This means that they are not attitudes based on needs, for example on needs for food, rest or security, but on the experience of duty. Moreover, they can be in confrontation with attitudes based on needs. The legal consciousness is a product of history which has emerged as a result of the mutual influence of various forces, such as powerful group interests, primitive instincts, traditional magic and religious ideas. ${ }^{27}$ Two distinctions of the legal consciousness can be made. The first is the distinction between the formal and the material legal consciousness which takes an important place in Ross's theory. The formal, or institutional, legal consciousness refers to the sense of the law-abiding attitude according to which the rulers appear as authorities. It is the specific feeling that a) the demands of the law, b) the claim for respect for these demands as well as c) force exercised in the name of the law, are not experienced as crude violence but as a rightful maintenance of the law. ${ }^{28}$ It can be concluded that this sense of disinterested duty refers to approval or disapproval of secondary norms and directives connected to the secondary norms. The material or moral legal consciousness refers to a feeling of approval or disapproval of the particular norms of behaviour, that is the prima-

\footnotetext{
26 Ross, op. cit. (note 2), at 369

27 Ibid. at 370

28 Ibid. at 54
} 
ry norms, demanded by legal institutions. ${ }^{29}$ For example, a material disinterested attitude is the attitude regarding the norm on the prohibition of abortion. The second distinction can be recognized in Ross's analysis of the legal consciousness with regard to subjects who possess the legal consciousness. In that sense, the legal consciousness can be the consciousness of citizens as well of legislators, judges and other officials, ${ }^{30}$ which can be seen as their introspective point of view regarding the primary or secondary norms of the legal system. As mentioned before, the legal consciousness is not necessarily in harmony between different actors. There is another characteristic important for an understanding of Ross's theory. When contemplating the relation between the legal consciousness and the legal order, Ross accepted the thesis on the mutual relationship between these two. On the one hand, the legal consciousness is to a certain extent determined by the existing legal order, while on the other hand, the legal consciousness exercises an influence on the legal order. ${ }^{31}$

Among the above-mentioned elements of the legal consciousness, for the purpose of this article we will briefly elaborate on Ross's account of the irrationality of the legal consciousness. He has differentiated two types of valuation of the legal order: valuation based on practical consideration and valuation based on the legal consciousness. The first one is rational and the second is irrational valuation. We can explain Ross's consideration on irrationality by following his two main propositions attributed to the legal consciousness: its origin in magic and religious ideas and its resistance to rational argumentation and justification. However, this irrationality is suitable for rationalisation through discovering interests which might be protected by the legal consciousness, and we can add through conditionalizing disinterested attitudes by other disinterested attitudes at least before we reach the last categorical attitude in the chain.

\subsection{THE TYPES OF NORMATIVE INFLUENCE}

As mentioned previously, Ross defines legal politics as the applied theory of legal sociology. It includes a description of the factors which can influence the acceptance of norms and the study of normative influence on the acceptance of norms. In the study of normative influence three main differentiations can be made.

The first difference can be discerned with regard to attitudes to be influenced by the normative change. Influence by means of interested attitudes is suitable for practical consideration and normative influence by means of disinterested attitudes is directly geared to the modification of the legal consciousness. The question arises if it is possible to influence the change of the legal consciousness by using norms aimed at interested attitudes? We have seen that Ross thinks this is possible because the irrationality of the legal consciousness can be removed by rational arguments. The first step in that case is to make interest which might exist

29 Ibid. at 56, 351-377.

30 The popular legal consciousness is mainly elaborated on in Chapter 17 of $O L J$; the legal consciousness of judges is exposed in Chapters 3 and 4 on normative ideology. 
in the background of the legal consciousness to appear on its surface. ${ }^{32}$ If this happens the conditionality of attitudes by interests leads to the 'rationalisation of the legal consciousness'.

The second differentiation of influences on attitudes towards norms can be made by taking into consideration the norms aimed to be accepted. The influence can be focused on acceptance of primary norms of behaviour of citizens (material legal consciousness), as well on approval of secondary norms on changing and applying the norms of the legal system, including directives on sources and interpretation as connected to the secondary norms (formal legal consciousness).

The third differentiation of normative influence refers to the main ways in which the legal consciousness can be modified. According to Ross, there are three ways: a) revolution, b) gradual cultural evolution whereby we add to Ross's consideration the thesis that normative influence can also have an impact on culture, and c) normative influence directed at modifying the legal consciousness in relation to particular primary or secondary norms. ${ }^{33}$ Revolution is modification without normative influence. The classification of the last two as belonging to the area of normative influence ${ }^{34}$ is justified by two of Ross's insights into the legal consciousness as a limiting factor for modifying the legal system. Based on Ross's insights on these obstacles two main types of influence on the legal consciousness can be differentiated: a) modification of the cultural consciousness, and b) harmonization of the legal consciousness with the cultural consciousness.

In the first case, obstacles to change in the fundamental legal institutions are such that normative change focused on the regulation of a controversial issue, according to Ross, has no influence on the change of consciousness. At first glance it seems that Ross agrees with Pound, according to whom the law can only express progress, but it cannot and does not lead to progress. However, when Ross is writing about the 'situation of no-influence on consciousness' he refers to the type of normative influence that would be directly geared towards modifying the legal consciousness on a particular legal issue. From the remainder of Ross's theory, it is clear that in this case of the legal consciousness as a limiting factor, it is still possible to influence the legal consciousness indirectly by influencing change of the cultural consciousness itself, which then enables change of the legal consciousness about controversial legal issues to be regulated by norms.

Ross has identified two cultural factors that can influence the modification of the legal consciousness: technical development and changes in conceptions of reality. ${ }^{35}$ We can conclude from the contemporary experience that deliberate change in these factors can lead to a change of the legal consciousness, while the modification of normative arrangements can influence both factors. Moreover, Ross noticed additional factors important for cultural modification: control of the communication channels for public debate and demonstration of experiences

32 Ibid. at 368, 370.

When referring to fundamental institutions, Ross emphasized that cultural tradition (consciousness) is not unchangeable. The fundamental legal institutions, supported by the legal consciousness, change along with evolution in the community and with revolution. Ibid. at 375 . The change of the legal system through harmonisation of the legal consciousness with the cultural consciousness takes up a large part of his writing on legal politics. 
regarding controversial differences. ${ }^{36}$ We can add to his insight that the course of public debate and demonstration of controversial experiences can also be governed by normative influences. One more insight must be added to Ross's analysis of cultural change. His analysis is based on the idea of progress prevailing in the Enlightenment movement and neglects the possibility that cultural change can move in different directions. For example, it is possible that insight into new technological changes and changes in conceptions of reality serves as an argument for the resistance of the legal consciousness to normative changes which leads to what some could consider progressive and others regressive change. Likewise, a public debate that would not be geared towards the Enlightenment idea of progress or would not be guided by a 'scientific' methodology of discussion, as well as the demonstration of negative experiences of encountering differences may affect the retention of what Ross would probably consider not progressive from his standpoint. The very idea of progress and evolution would be better replaced with the term 'the modification of the cultural consciousness'.

In the second case, the obstacle to the modification of the legal system is that the legal consciousness does not follow the cultural modification of the community. Since there is already 'progress' in the evolution of the community, the task of normative influence is only to properly state that progress and "gently adjust the legal system to the changed technical and ideological conditions." 37 This manner of change is in accordance with Roscoe Pound's thesis that law can only express progress. ${ }^{38}$ As explained above, we can correct this thesis to be more descriptive and talk about the modification of the cultural consciousness instead of progress in the evolution of the community. Thereby in this case, by changing the legal system, the legal consciousness is gradually aligned with the cultural consciousness towards the individual and community life.

Normative influence on the legal consciousness in this case depends on pre-existing attitudes in the cultural consciousness and consists of normative activity aimed at overcoming the legal consciousness lagging behind the cultural consciousness. Cultural modification could be followed by normative influence on interested and disinterested attitudes. Modification of the cultural consciousness related solely to technology is more suitable to be addressed by normative influence based on the interested attitude, and modification solely related to conceptions of reality could be expected to be followed by normative influence on disinterested attitudes.

\section{NORMATIVE INFLUENCE ON THE HARMONISATION OF THE LEGAL CONSCIOUSNESS}

The specific object of the study of normative influence is normative influence on the legal consciousness. It can be defined as a set of norms that modify the legal consciousness in such a way as to accept a norm that has not been accepted until then. Normative influence on the

\footnotetext{
36 Ibid.

37 Ibid. at 377

38 Pound, Roscoe, Jurisprudence, Vol III, The Lawbook Exchange Ltd., Union, New Jersey, 2000, at 372.
} 
legal consciousness can be aimed at modification of the cultural consciousness and on harmonization of the legal consciousness with the cultural consciousness. Ross's elaboration of normative influence on the harmonisation of the legal consciousness can be structured by considering: a) the techniques of normative influence and b) the limitations of normative influence.

\subsection{THE TECHNIQUES OF NORMATIVE INFLUENCE}

When 'normative influence on the legal consciousness' is engaged then "more detailed shaping of the legal consciousness in manageable rules of law must observe technical considerations based on sociological knowledge or estimates." ${ }^{39}$ Ross's position brings us to the different techniques that can be used in social engineering. These techniques can be explained in more detail following Ross's insights on a) the introduction and efficient application of legal norms and b) Stevenson's analysis of ethical disagreements used by Ross.

The first technique refers to the introduction of proper content into the legal system and its efficient application. Ross's analysis, similar to that of Roscoe Pound, emphasises the importance of transferring the law in books into the law in action. In the first step the content of the norm has to converge with the cultural attitudes of society. ${ }^{40}$ The second step requires establishing an operational belief according to which the introduced norm actually contributes to the realisation of cultural attitudes. This belief can be established through the efficient application of the norm. Both Ross and Pound emphasize the role of the courts for the law in action. ${ }^{41}$ Alf Ross considers the application of law through courts which order the use of force as important for the maintenance of the legal order. ${ }^{42}$ We would make the same argument from a different point of view. As we will see soon, according to Ross even in cases when an agreement on an attitude exists there could still be disagreement on the operational belief. The lack of an operational belief that the norm indeed brings the desired results could be avoided if the courts have developed case law proving that the norm in practice brings about the desired results.

The following two techniques refer to Ross's analysis of conflicting and divergent attitudes, taken from Stevenson's theory on ethical disagreements ${ }^{43}$ which can be resolved by techniques of influence on distracting operational beliefs and attitudes. The use of these techniques presupposes that one attitude can be conditioned by another. In one case two agents take opposite sides concerning the desirability of the object of a norm and in the other case two agents agree on the desirability of two attitudes but attach a different weight to each of them. ${ }^{44}$ If we

39 Ibid. at 377.

40 This thesis can be recognized in Pound's idea that law has to express progress and in his view on the need for rule to reflect the needs of those submitted to that rule. Pound, op. cit. (note 38) at 372.

41 According to Pound the abstract formulation of rules is likely to result in empty formulas unless case law is developed through bringing controversies into courts. Pound, op. cit. (note 38) at 373 . Ross insisted in his theory of law on the law in action as the law decided by courts.

42 Ross, op. cit. (note 2) at 53.

43 Stevenson, Charles L., 1958. Ethics and Language. London: Oxford University Press, at 180. 
apply this model to the relationship between the legislator and addressees of the norm, then the techniques of influence through conditionalizing attitudes will correspond to those presented in Ross's description of conflicting and divergent attitudes. ${ }^{45}$

\subsection{THE LIMITATIONS OF NORMATIVE INFLUENCE}

Ross has identified the limits of normative influence on interested attitudes which could also be an obstacle for modifying the legal consciousness. We will start with his explication and then question the applicability of his thesis on normative influence on the disinterested attitudes themselves. After his initial optimism with regard to the 'rational capacity' of the legal consciousness, Ross notes that normative influence based on interested attitudes cannot be used in two situations. ${ }^{46}$

1. The first is the situation of indifference of the legal consciousness to interests. We can distinguish two sub-cases here. (a) The first, described by Ross, is the sub-case when the normative arrangement itself may be indifferent to interests. For example, norms for driving on the right side of the road cannot be related to any interest. (b) From Ross's example, we can add another case when an interest can be discovered but the disinterested attitude associated with the norm is strong enough that the interested attitude does not have any influence at all.

2. The other situation refers to the limited possibilities of knowledge. Ross states that in some normative changes the level of knowledge is such that we cannot form a well-founded view of the social consequences of possible solutions and we do not know which solution leads to a possible interest. For example, answering the question of what form of marriage - monogamous or polygamous - should be regulated by law can hardly be justified by the scientifically proven effects of such arrangements on any interest. In other words, this is a situation where it is impossible to influence an operational belief which connects norms and attitudes or the attitudes themselves. ${ }^{47}$

According to Ross, when a rational argument relating to interest is not possible or has poor directing power, the current legal consciousness assumes a leading role. ${ }^{48} \mathrm{We}$ may conclude that in such cases the legal consciousness can be changed only directly through influence on the disinterested attitude of the existing legal consciousness by other disinterested attitudes.

Ross has not specifically elaborated the limitations of normative influence on disinterested attitudes used in order to modify the legal consciousness. Nevertheless, we could question whether the same insights which he used to explain the limitations of normative influence on interested attitudes, at least in some cases, are applicable for a description of the possible limitations of normative influence on disinterested attitudes. Two cases can be differentiated in the following way.

45 Ross has discussed the problem of conflicting and divergent interested attitudes but there is no reason why the same problems and techniques could not also be applicable to disinterested attitudes.

46 Ibid. at 374.

47 Ibid. at 375

48 Ibid. at 376 
In the first case the techniques of harmonisation can be applied to the disinterested attitudes. The sub-case of the first limitation that was mentioned for interested attitudes does not refer to disinterested attitudes since the legal consciousness is shaped itself by disinterested attitudes. Nevertheless, in the same vein, as with the second sub-case mentioned for the first limitation of the influence on interested attitudes, a stronger pre-existing disinterested attitude can be an obstacle for a new disinterested attitude introduced by a new norm. The second limitation that Ross has put forward for influence on interested attitudes could appear as an obstacle for disinterested attitudes, and that is the limited capacity of knowledge regarding the effects of a norm which disables the impact of strengthening operational beliefs between a norm and a disinterested attitude. In the second case, the disinterested attitudes are categorical ones and cannot be conditioned by any other attitudes. In this case, the disinterested attitude can only be changed by normative influences on the modification of the cultural consciousness.

\subsection{NORMATIVE INFLUENCE ON THE FORMAL LEGAL CONSCIOUSNESS}

Although Ross has not specifically elaborated normative influence on the acceptance of secondary rules, we consider it important to further develop his theory through a comprehensive analysis of normative influence on the formal legal consciousness. The significance of this analysis could appear, for instance, when a state accedes to an association of states such as the EU which requires the introduction of a new mode of changing and applying the law in the acceding state. Another interesting situation can be the process of the constitutionalization of a legal order which requires courts to accept a new mode of changing the legal system.

The analysis will be based on Ross's definition of the formal legal consciousness and the thesis on the conditioning of attitudes. The formal legal consciousness denotes disinterested attitudes towards secondary norms on the creation and application of the law, including directives on the sources and interpretation of norms connected to secondary norms. If a norm N1 on the mode of changing or applying norms is introduced in the legal system, the formal legal consciousness may reject such a normative change or the existing N1 could be subsequently disapproved by the formal legal consciousness. The aforementioned techniques of normative influence on the legal consciousness, thanks to the very examples due to which they came about, are primarily designed to describe normative impact on the material legal consciousness regarding primary norms of behaviour. However, since the norms and attitudes are conceptual elements in both the formal and material legal consciousness, a prima vista there is no reason why the same techniques could not be utilized to influence both attitudes. The thesis will be tested by distinguishing four possible cases we can imagine.

a) In the first case, the formal legal consciousness consists of a categorical disinterested attitude towards some mode of changing and applying the norms without any conditionalizing attitudes behind it. It is about an unconditioned feeling of duty to respect some norms on legislation or adjudication in and of themselves, for example a sense of loyalty to the king, a sense of duty not to access a specific association of states or a sense of duty not to leave a specific union of states. 
b) The second case refers to the legal consciousness consisting of a disinterested attitude towards a secondary norm which is not categorical like in the first case but conditioned by other disinterested or interested attitudes in the conditioning chain. The conditioning attitudes in this case refer to the characteristics of authorities, that is who should change or apply the norms and how, regardless of the content of changing or application itself. Examples of conditioning interested attitudes are the following. Citizens may have a positive attitude regarding the norms on their participation as a jury in court proceedings because of the interested attitude towards judicial authorities under the influence of citizens regardless of the content of judgements; judges may have a negative attitude towards norms which enable them to participate in changing the legal system by the application of the constitution because of an interested attitude against the authorities which requires investment of their human resources which they consider they do not have. In the same vein, a disinterested attitude can be worked out. Judges may have a negative attitude against the norms which empower them to supervise a legislative body and thus participate in norm-creation because of a disinterested attitude towards the legislator as the only body empowered to create norms; citizens may have a positive attitude regarding the norms on transnational or international adjudication because of a disinterested attitude towards the authorities which make decisions based on international or transnational law regardless of the content of their decisions.

c) In the third case a disinterested attitude towards a secondary norm is conditioned by an attitude towards a general idea on the content of the law that is, under the influence of the cultural consciousness, expected to be produced by the norms of changing or applying the law. For example, through an interested attitude towards the wealth of the nation which is believed to be protected by the democratic mode of norm-creation, a disinterested attitude towards the national culture or identity which is believed to be endangered by the transnational mode of norm-creation or an interested attitude towards the freedom of the market which is believed to be improved by the transnational mode of norm-creation and norm-application.

d) In the fourth case the formal legal consciousness on secondary norms is conditioned by attitudes towards the primary norms really produced by the authorities.

In the first case we cannot speak of the harmonization of the cultural and legal consciousness and the techniques of normative influence are not possible. The only possibility for the modification of the categorical disinterested attitude towards changing and applying the norms is the modification of the cultural consciousness itself regarding the categorical attitude to the secondary norm. In the next three cases it is possible to influence the formal legal consciousness through the technique of conditionalizing attitudes. In the second case, normative influence can be, for example, directed at strengthening operational beliefs between attitudes regarding secondary norms and attitudes towards the characteristics of the authorities empowered by norms to participate in changing and applying the law. In the third and fourth cases normative influence could be focused on strengthening the operational beliefs between the attitudes towards the secondary norms and the attitudes towards the content of the law that is perceived to be produced by the specific mode of norm-creation and norm-application. In all these cases influence can be applied on the distracting operational beliefs and attitudes. 
The modification of the formal legal consciousness can be an interesting subject for research. In some circumstances, for the acceptance of new norms on changing and applying the law, the characteristics of the authorities could be more important than the primary norms produced by these institutions. ${ }^{49}$ If we follow Ross, we could conclude that with time the formal legal consciousness becomes more and more dependent on the material legal consciousness influenced by the production of expected results. If the produced norms on behaviour deviate from expectations under the influence of the cultural consciousness, important operational beliefs are weakened and the formal legal consciousness shifts towards denying support to the institutions. ${ }^{50}$

\section{CONCLUSION: ROSS'S THEORY REACTIVATED}

In this article we have tried primarily to present and re-construct Ross's theory to manifest how his insights can be used as a theoretical ground for researching the process of norm-changing. Through some further developments of his thesis we have tried to make his theory more suitable for contemporary sociological research. We can agree with Julius Stone ${ }^{51}$ that his theory is based on the insights of some other authors belonging to the sociological jurisprudence camp. But this does not undermine his direct contribution to legal sociology as noticed by Delberg-Larson. ${ }^{52}$

Moreover, we are of the opinion that Ross's analysis is not only important for a better understanding of the specific legal practice of deliberate legal system change, but also of legal phenomena in general, as Ross understood them. Ross's methodological approach to law and the place of his theory on deliberate normative change in his general theory could make his insights appear to be more successful than Eric Millard ${ }^{53}$ proposes. Namely, Ross's theory on deliberate normative change contributes to a better understanding of the conceptional elements and the methodology of his general theory of law. Regarding the understanding of the conceptions of his theory we should mention that an understanding of Ross's theory of adjudication will remain incomplete if the connections between adjudication, deliberate normative change and the legal consciousness are not considered. Additionally, an understanding of his concept of legal validity is incomplete without Ross's account of the legal consciousness and its influence on the content of a particular legal system and the process of changing that content.

49 For an indication of the empirical confirmation of such a thesis see: Burazin, Luka, Krešić, Mario. How Much Do Croatian Citizens Know About the EU Institutions and Law and What Are Their Attitudes Towards Them? Importance of Empirical Research for Legal Theory. In Knowledge Of and Attitudes Towards European and International Law in the Republic of Croatia, 2012, edited by Šimonović, Ivan, 85-108. Zagreb: University of Zagreb.

50

Ross, op. cit. (note 2) at 55.

Julius Stone, Social Engineers and Rational Technologists, Stanford Law Review, Vol. 13, No. 3.

Jørgen Dalberg-Larsen, Alf Ross and the Sociology of Law, Scandinavian Studies in Law 48, at 47.

"The modern realism in Europe (the Genoa or Nanterre Schools, for instance) has considered that this part of Ross's work should be allowed to remain in the books as a testimony of a given period, and of the human problems of that period. This author sees no reason to reactivate it, neither for the good of an empiricist theory of law, nor for the ends of giving a non-realist foundation to dogmatics." Eric Millard, Alf Ross on legislation, in: The Theory and Practice of Legislation, Volume 1, Number 1, June 2013, Realist Conceptions of Legislation, eds. P. Brunet, E. Millard, P. Mindus, at 89. 
With the aim of strengthening the thesis on the importance of Ross's theory for a better understanding of his methodological approach to law we will return to the introduction of this article and place deliberate normative change as explained by Ross in the context of his scientific approach to law. As has been mentioned in the introduction, Ross's scientific approach to the law can be interpreted as consisting of two phases: a) a description of the existing activities of the participants in different practices connected to the law and b) an explanation of these practices through the model of science. At both levels Ross defends the postulates of falsifiability, rationality, monistic ontology and non-cognitivism. Following this distinction, we can summarize his deliberate normative change theory.

A scientific description of the existing practice of norm-changing includes the following thesis. (1) It is determined by the cultural consciousness and the legal consciousness influenced by the cultural consciousness. The popular consciousness, legislators' and judges' consciousnesses can conflict with each other. (2) The selection of the goals of norm-changing is influenced by cultural conceptions of the world, including conceptions of just order, which are a matter of preference and not of cognition. (3) The process of norm-changing can be led by attitudes based on needs and attitudes based on duties. The regularities of the appearance of attitudes towards norms can be detected and influenced by legal norms.

The scientific model of norm-changing comprises the following elements. (1) It is grounded on scientific insights into the factors determining norm-changing. The model is rational regarding the selection of goals and methods to reach the goals. (2) The first element of rationality regarding the goals of deliberate normative change is its aim to satisfy needs reflected in interested attitudes. The second element of rationality is Ross's democratic model of the selection of goals whose values correspond to the values of science. This model requires open communication channels for public debate and demonstration of experiences regarding controversial differences which contributes to rational choice. (3) The model is rational regarding the methods used to reach the best possible results based on an understanding of normative influence (social engineering).

\section{BIBLIOGRAPHY}

1. Luka Burazin; Mario Krešić, How Much Do Croatian Citizens Know About the EU Institutions and Law and What Are Their Attitudes Towards Them? Importance of Empirical Research for Legal Theory. In: Knowledge of and attitudes towards European and International law in the Republic of Croatia, 2012, edited by Šimonović, Ivan, Zagreb: University of Zagreb.

2. Jørgen Dalberg-Larsen, Alf Ross and the Sociology of Law, Scandinavian Studies in Law 48.

3. Edoardo Fittipaldi, Introduction: Continental Legal Realism in: Enrico Pattaro, Corrado Roversi (ed.), Legal Philosophy in the Twentieth Century: The Civil Law World, Tome II.

4. H. L. A. Hart, Essays in Jurisprudence and Philosophy, Oxford University Press, 1983.

5. Marc Hertogh, A 'European' Conception of Legal Consciousness: Rediscovering Eugen Ehrlich, Journal of Law and Society Volume 31, number 4.

6. Jakob v. H. Holtermann, A Straw Man Revisited: Resettling the Score between H.L.A. Hart and Scandinavian Legal Realism, 57 Santa Clara L. Rev. 1 (2017). 
7. Eric Millard, Alf Ross on legislation, in: The Theory and Practice of Legislation, Realist Conceptions of Legislation, eds. P. Brunet, E. Millard, P. Mindus, Volume 1, Number 1, June 2013.

8. Patricia Mindus, Axel Hägerström on Law-making, in: The Theory and Practice of Legislation, Realist Conceptions of Legislation, eds. P. Brunet; E. Millard; P. Mindus, Volume 1, Number 1, June 2013.

9. Karl Popper, The Logic of Scientific Discovery, Routledge, London and New York, 2002.

10. Roscoe Pound, Jurisprudence, Vol III, The Lawbook Exchange Ltd., Union, New Jersey, 2000.

11. Amelie O. Rorty, On Law and Justice by Alf Ross Review, Ethics, Vol. 70, No. 2, 1960.

12. Alf Ross, On Law and Justice, The Lawbook Exchange, Ltd, Clark, New Jersey, 2004.

13. Alf Ross, Why democracy?, Harvard University Press, 1952.

14. Torben Spaak, Karl Olivecrona on Legislation, in: The Theory and Practice of Legislation, Realist Conceptions of Legislation, eds. P. Brunet, E. Millard, P. Mindus, Volume 1, Number 1, June 2013.

15. Charles L. Stevenson, Ethics and Language. London, Oxford University Press, 1958.

16. Julius Stone, "Social Engineers and Rational Technologists", Stanford Law Review, Vol. 13, No. 3.

17. Jeremy Waldron, The Dignity of Legislation, Cambridge University Press, New York, 1999. 
Mario Krešic ${ }^{*}$

\section{ROSSOV POJAM PRAVNE SVIJESTI I NAMJERAVANA NORMATIVNA PROMJENA}

\section{Sažetak}

Svjesna i voljna normativna promjena ključan je proces u modernim pravnim poredcima, iako se često u teoriji prava poima kao njezin periferni dio. Članak analizira stavove Alfa Rossa o ulozi pravne svijesti za razumijevanje namjeravane normative promjene. Neki Rossovi uvidi dodatno su razrađeni kako bi se pokazala primjenjivost njegove teorije na istraživanje suvremenih pravnih procesa. Iako zanemarena u teoriji prava, Rossova teorija namjeravane normativne promjene značajan je doprinos razumijevanju i proučavanju pravne prakse. Uz to, ona predstavlja sastavni dio njegove opće teorije o pravu što posebno dolazi do izražaja kada se teorija namjeravane normativne promjene promatra u svijetlu Rossova znanstvenog pristupa pravu.

Ključne riječi: $\quad$ pravna svijest, namjeravana normativna promjena, Alf Ross, znanost, normativni utjecaj

\section{(c) (i) (2)}

This work is licensed under a Creative Commons

Attribution-NonCommercial 4.0 International License.

* Dr. sc. Mario Krešić, docent, Pravni fakultet Sveučilišta u Zagrebu, Trg Republike Hrvatske 14, 10000 Zagreb, Republika Hrvatska. Adresa e-pošte: mario.kresic@pravo.hr. ORCID: https://orcid.org/0000-0002-0014-4157. 